\title{
Climate Change and Sensitivity of Surface Water Resources in the Mekrou Sub-Watershed at the Yakrigourou Outlet (North Benin / West Africa)
}

\author{
Alain Ibikunle Ague ${ }^{1, ~ *}$, Cyr Gervais Etene ${ }^{2}$, Somiyabalo Pilabina ${ }^{3}$, Ibouraima Yabi ${ }^{2}$ \\ ${ }^{1}$ Multidisciplinary Doctoral School "Spaces, Cultures and Development", University of Abomey-Calavi, Godomey, Benin \\ ${ }^{2}$ Pierre PAGNEY Laboratory on Climate, Water, Ecosystem and Development, Department of Geography and Land Management, University \\ of Abomey-Calavi, Godomey, Benin \\ ${ }^{3}$ Laboratory of Research on Spaces, Exchanges and Human Security (LaREESH), Department of Geography, University of Lome, Lome, \\ Togo
}

Email address:

ibikalain@yahoo.fr (A. I. Ague)

${ }^{*}$ Corresponding author

\section{To cite this article:}

Alain Ibikunle Ague, Cyr Gervais Etene, Somiyabalo Pilabina, Ibouraima Yabi. Climate Change and Sensitivity of Surface Water Resources in the Mekrou Sub-Watershed at the Yakrigourou Outlet (North Benin / West Africa). International Journal of Environmental Monitoring and Analysis. Vol. 9, No. 3, 2021, pp. 60-66. doi: 10.11648/j.ijema.20210903.12

Received: April 9, 2021; Accepted: May 5, 2021; Published: May 20, 2021

\begin{abstract}
The present work aims to contribute to a better understanding of the impacts of climate change on the availability of surface water resources in the Mékrou sub-basin at the Yakrigourou outlet in northern Benin. To achieve this objective, descriptive statistical methods were applied to hydro-climatological data. The historical data were taken from the Météo-Bénin database and from the General Directorate of Water in Benin. The simulation data are those of the HadGEM2-ES climate model under the RCP 4.5 and RCP 8.5 scenarios and then at horizons 50 (2041 to 2060) and 70 (2061 to 2080). The results show that the period from 1965 to 2018 is globally characterised by a strong irregularity of rainfall with a decreasing trend and a multiplication of dry years estimated at $54 \%$. In the same way, the runoff decrease about $5.8 \mathrm{~m}^{3} / \mathrm{s}$ during the decade 2007 2016. Under the most pessimistic scenario (RCP8.5) and compared to the reference period (1971-1990), the HadGEM2-ES model predicts an increase in annual precipitation estimated at $8.29 \%$ by $2041-2060$ and $13.83 \%$ by $2061-2080$. As regards temperature, there could be an increase of $2.4^{\circ} \mathrm{C}$ by $2041-2060$ and $3.7^{\circ} \mathrm{C}$ by $2061-2080$. These climatic events affect the availability of surface water resources in the sub-basin.
\end{abstract}

Keywords: Climate Change, Sensitivity, Water Resources, Mekrou Sub-basin

\section{Introduction}

The climatic parameters that play a role in the availability of water resources are mainly precipitation, temperature and evaporative demand [1]. On a global scale, the scientific community is unanimous about the impact of variations in these parameters on surface water resources and its corollaries. Indeed, according to projections, increases in precipitation intensity and variability are expected to increase the risk of floods and droughts in several regions [2] and global warming of $2^{\circ} \mathrm{C}$ rather than $1.5^{\circ} \mathrm{C}$ would increase the risk of water scarcity in some regions [3].

In Africa, and mainly in West Africa, climate change is manifested, among other things, by increased variability in rainfall, increases in maximum temperatures of 0.5 to $0.9^{\circ} \mathrm{C}$ and beyond $+1{ }^{\circ} \mathrm{C}$ for minimum temperatures [3].

In Benin, several authors including [4 - 12] have shown that the climatic physiognomy has undergone changes.

In Mekrou catchment, Vissin [13] showed that for a rainfall deficit of -12\% during the sub-period 1973-1992 compared to $1955-1972$, there is a $72 \%$ decrease in runoff. Similarly, in the same area, by using a set of three Climatics Models (MPIREMO, DMI-HIRHAM5 and SMHI-RCA4), Obada and al., [14] indicates an increase in rainfall amounts over the period 2071 - 2100 for the RCP 4.5 and RCP 8.5 scenarios. Yabi [15] showed that the Sudanian zone of Benin, to which the Mekrou 
basin belongs, is affected by the phenomenon of drought, which manifests itself in particular through significant rainfall deficits, late onset and early cessation of rainfall, and the appearance of dry sequences. These results show the complexity of climate change, whose impacts on water resources are obvious and can vary from one hydrological subunit to another. What then are the effects of the variation of climatic parameters on the surface water resources of the Mekrou sub-basin at the Yakrigourou outlet? The present article aims to provide a solution to this question by characterising climate variability and its impact on surface water resources in the Mekrou sub-basin at Yakrigourou.

The Mekrou sub-basin at the Yakrigourou outlet is located in the northern part of Benin between $10^{\circ}$ and $10^{\circ} 50^{\prime}$ North latitude and between $1^{\circ} 31^{\prime}$ and $2^{\circ} 10^{\prime}$ East longitude (Figure 1). It covers an area of about $2643 \mathrm{~km}^{2}$ and is spread over four communes, namely Kouandé (59\%), Kérou (19\%), Péhunco (21\%) and Natitingou (2\%).

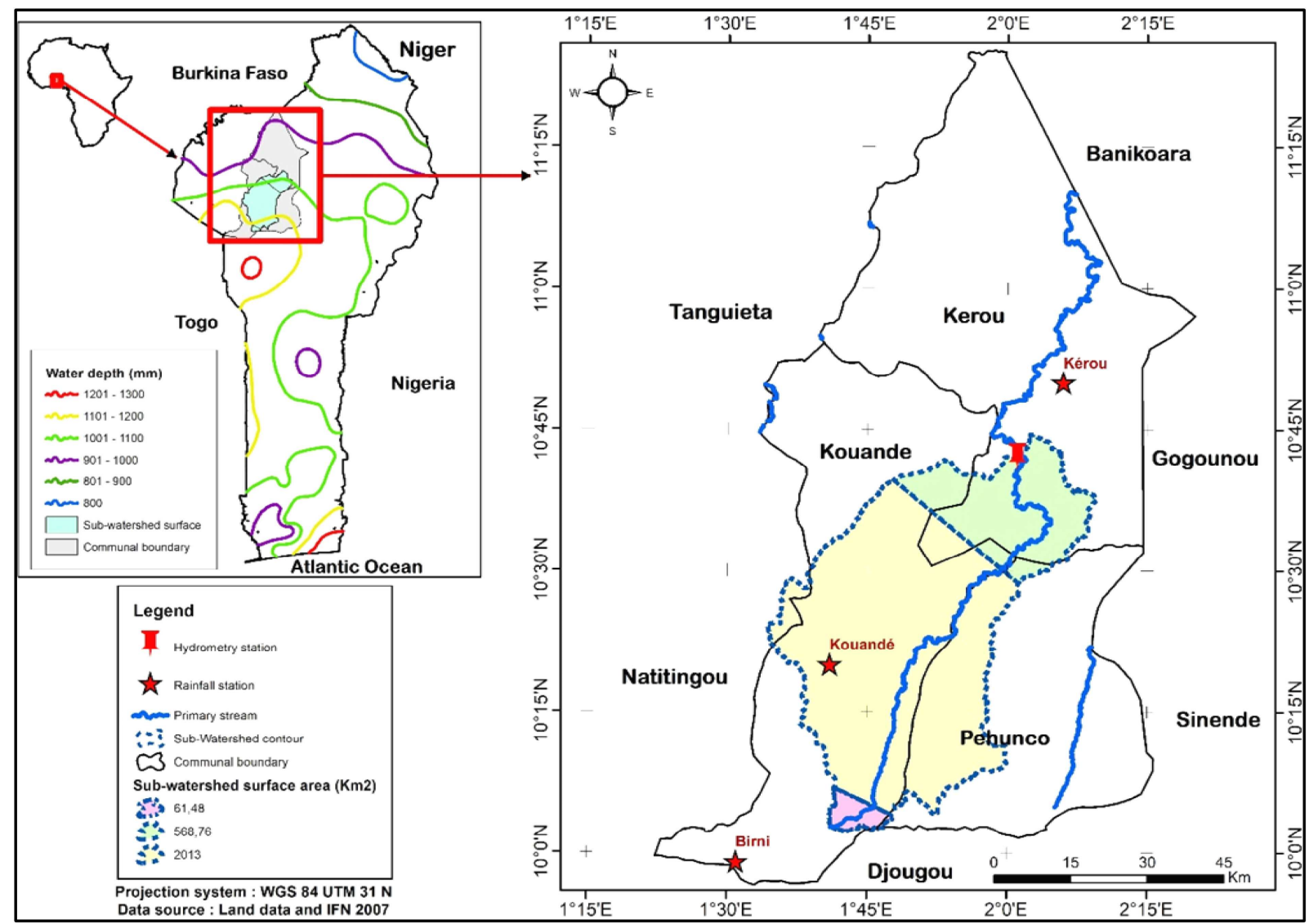

Figure 1. Study area.

\section{Data and Methods}

\subsection{Data}

The climatic data used in this study include monthly rainfall from three rainfall stations (Birni, Kouandé and Kérou) belonging to the study basin region, monthly temperatures and potential evapotranspiration from the synoptic station of Natitingou. They are collected from Benin Meteorology agency. Historical rainfull and temperature data cover globally the period 1965 to 2018 . The future data concern the HadGEM2-ES (Hadley Global Environment Model 2 - Earth System) climate model under the RCP 4.5 and RCP 8.5 scenarios and at horizons 50 (2041 to 2060) and 70 (2061 to 2080). They come from the archives gathered under the World Climate Research Programme (WCRP) Coupled Model Intercomparison Project 5 (CMIP5) [16]. The hydrometric data used are obtained from the hydrology department of the Directorate General of Water in Benin. These are daily flows from the Yakrigourou station over the period 2007 to 2019 .

\subsection{Methods}

The rainfall average one the sub-basin has been calculated Thiessen method written as (1) because the application is easy [17]. La figure 1 présente aussi les aires du bassin délimitée par le polygone de Thiessen. Figure 1 also shows the areas of the basin delimited by the Thiessen polygon.

$$
\bar{P}=\sum_{i}^{n} \frac{S_{i} P_{i}}{S}
$$

$\bar{P}$ : rainfall average in the sub-basin;

$S_{i}$ : Sub basin area délimitated by Thiessen polygon for the station « $i »$;

$P_{i}$ : Annual rainfall for the station $« i »$; 
$P_{i}$ : Total surface of the sub-basin.

The Standardised Index (SI) has been used for the determination of dry and wet years for precipitation and cool and warm years for temperature. This index is used by several authors including [18] and is writting by the following formula (2):

$$
S I_{a}=\frac{X_{a}-X_{m}}{\sigma_{x}}
$$

This formula was applied to the rainfall, temperature and flow data.

When considering rainfall data, $X_{i}$ is the annual rainfall average for the year «a» in the sub-basin; $X_{m}$ and $\sigma_{x}$, are respectively the mean and standard deviation of the annual rainfall in the sub-basin.

To analyse the Standardised Precipitation Index, we considered the severity thresholds established by the standard deviation method presented in Table 1 [19].

Table 1. Classification of drought indicators.

\begin{tabular}{ll}
\hline SPI values & Classes \\
\hline More than 2.0 & Extremely wet \\
1,5 à 1,99 & Severely wet \\
1,0 à 1,49 & Moderately wet \\
$-0,99$ à 0,99 & Near normal \\
-1.0 à $-1,49$ & Moderately dry \\
$-1,5$ à $-1,99$ & Severely dry \\
Less than $-2,0$ & Extremely dry \\
\hline
\end{tabular}

Climate change is analysed using the methods of [20] and [21] also used by [16]. They meet the following formulas (3):

$$
D_{\text {horiz }}=\bar{P}_{\text {horiz }}-\bar{P}_{\text {ref }} \text { and } E_{\text {horiz }}=\frac{\bar{P}_{\text {horiz }}-\bar{P}_{\text {ref }}}{\bar{P}_{\text {ref }}} * 100
$$

where D is the relative difference, $\bar{P}_{\text {horiz }}=$ average horizon 50 (2041-2060) or horizon 70 (2061-2080), $\bar{P}_{\text {ref }}=$ average for the reference period (1971-1990) and $E=\%$ difference corresponds to the relative increase or decrease in average precipitation or temperature (horizon 2050 or 2070) compared to the average of the reference period (1971-1990).

The availability of water resources is analysed by the climate balance (4) also used by [13]:

$$
B C=P-E T P
$$

Where $B c$ is the climatic balance in $\mathrm{mm}, P$ is the rainfall in $\mathrm{mm}$ and ETP means the potential evapotranspiration in $\mathrm{mm}$.

If $B c>0$, the balance is surplus; if $B c<0$, the balance is deficit and if $B C=0$ the balance is balanced.

\section{Results}

\subsection{Current Hydro-climatic Trends in Mekrou Sub-basin at Yakrigourou}

\subsubsection{Rainfall and Thermal Variability in Mekrou Sub-basin at Yakrigourou}

Figures 2 and 3 presented respectively the variation of the standardised rainfall index and the temperature in the sub- basin of the Mekrou at Yakrigourou.

The analysis of figure 2 shows that the period (1965 2018) is globally characterised by a strong irregularity of rainfall with a downward trend estimated at about $14.4 \%$. There has also a multiplication of the number of dry years, estimated at 54\% and covering the years from 1980 to 1990 . The years 1983 and 1992 show a severe drought with an index of 1.77 and 1.71 respectively. At the same time, figure 3 shows that $56 \%$ of years including the period from 1998 to 2012 were warm. By the moving average, we observe an increasing trend of the average temperature, estimated at $0.4^{\circ} \mathrm{C}$ in the sub-basin.

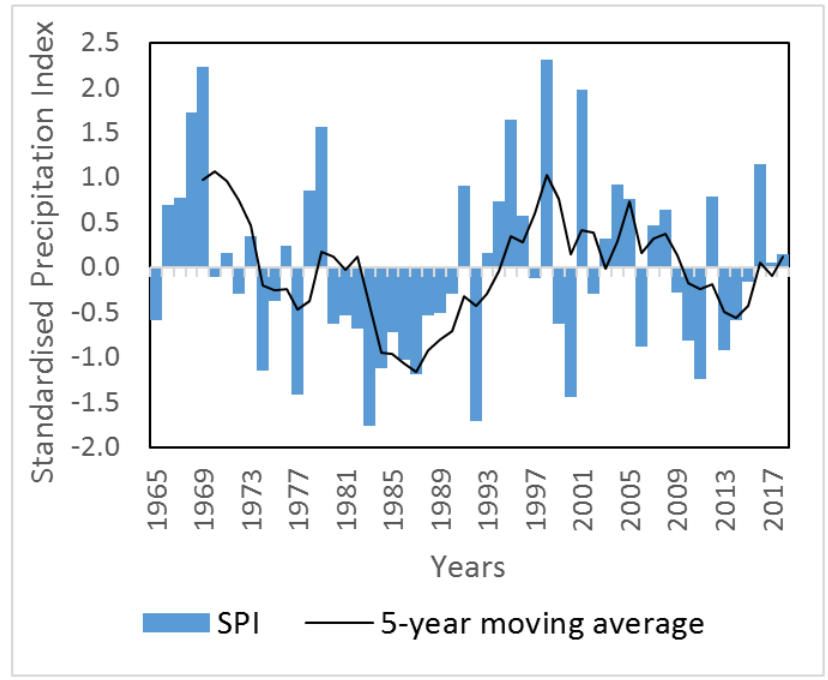

Figure 2. Evolution in the standardised precipitation index.

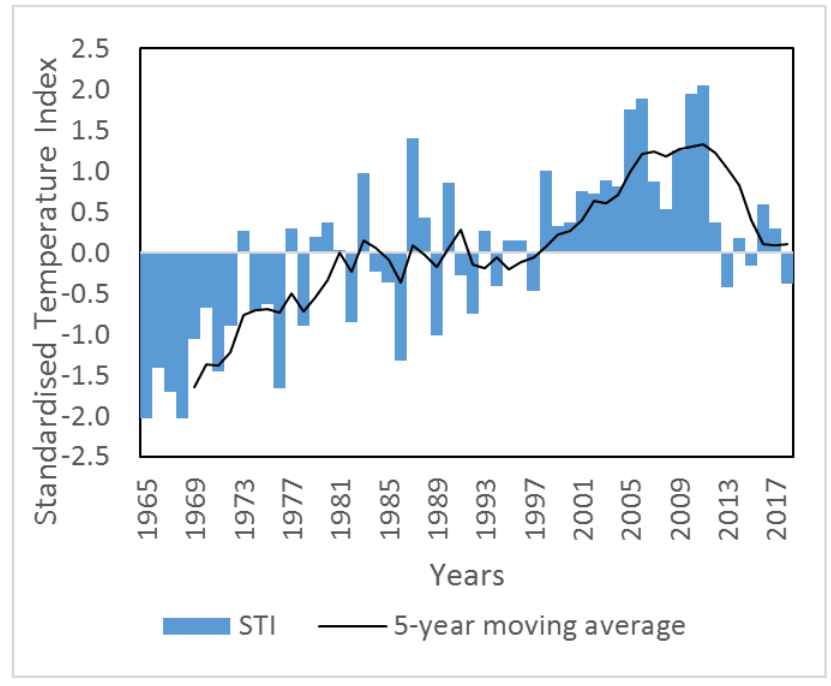

Figure 3. Evolution in the standardised temperature index.

\subsubsection{Flow Variability in Mekrou Sub-basin at Yakrigourou}

Figure 4 shows the inter-annual variability of the Mekrou flow in Yakrigourou. From the analysis of this figure, it can be seen that the evolution of the indices shows an important variation of the flows in the sub-basin. The moving average has allowed for a better visualization of the variation of flows and clearly shows the decade from 2007 to 2016 as a dry 
period with a decrease in flow by $5.8 \mathrm{~m}^{3} / \mathrm{s}$. We also note that the period from 2017 to 2019 is wet.

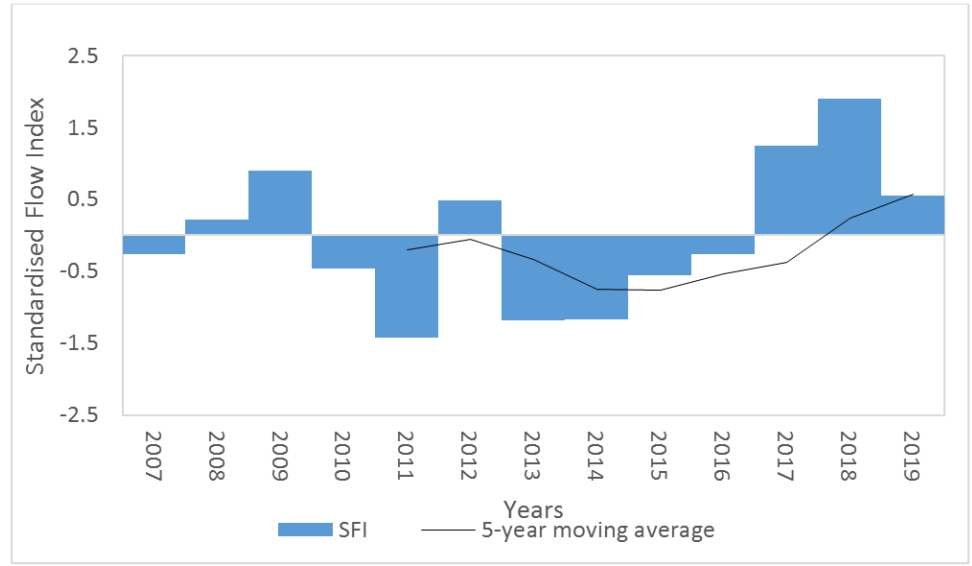

Figure 4. Evolution of the standardised flow index between 2007 and 2019 at Yakrigourou.

\subsection{Climate Projections in Mekrou Sub-basin at Yakrigourou}

Table 2 presented the variation of annual rainfall mean for horizon (2041-2060) and the horizon (2061-2080) compared to the reference period (1971-1990) under the RCP 4.5 and RCP 8.5 scenarios.

Table 2. Projected change in annual average precipitation.

\begin{tabular}{lllll}
\hline & \multicolumn{2}{l}{ RCP 4.5 Scenario } & \multicolumn{2}{l}{ RCP 8.5 Scenario } \\
\cline { 2 - 5 } & $\begin{array}{l}\text { Average } \\
(\mathbf{m m})\end{array}$ & $\begin{array}{l}\text { Variation } \\
\mathbf{( \% )}\end{array}$ & $\begin{array}{l}\text { Average } \\
(\mathbf{m m})\end{array}$ & $\begin{array}{l}\text { Variation } \\
\mathbf{( \% )}\end{array}$ \\
\hline Horizon 50 (2041 - 2060) & 1212.67 & 6.62 & 1231.67 & 8.29 \\
Horizon 70 (2061 - 2080) & 1241.33 & 9.14 & 1294.67 & 13.83 \\
\hline
\end{tabular}

The analysis of this table shows that the HadGEM2-ES model predicts an increase of annual rainfall for all scenarios. According to the RCP 4.5 scenario, this increase is estimated at $6.62 \%$ between the periods $1971-1990$ and 2041-2060 and $8.29 \%$ between 1971-1990 and 2061-2080. When considering the most pessimistic scenario (RCP 8.5), those percentages rise respectively to $8.29 \%$ and $13.83 \%$. On a monthly scale (Figure 5), the month of April, which currently marks the start of the rainy season, will experience a decrease in rainfall, whatever the scenario and the time horizon. This decrease is estimated at $-14.5 \%$ under RCP 4.5 and $-8.5 \%$ under RCP 8.5 at horizon 50, then at $-10.2 \%$ under RCP 4.5 and $-9.2 \%$ under RCP 8.5 at horizon 70 . On the other hand, the month of March, currently in the dry season, will experience an increase of rainfall. The increase is more significant in the rainy months, particularly August and September, and could lead to flooding in the sub-basin.

Considering the temperature, we note that the model predicts an increase by $1.6^{\circ} \mathrm{C}$ under RCP 4.5 and $2.4^{\circ} \mathrm{C}$ under RCP 8.5 on the horizon $2041-2060$ and also by $2.2^{\circ} \mathrm{C}$ under RCP 4.5 and $3.7^{\circ} \mathrm{C}$ under RCP 8.5 on the horizon 2061-2080. In addition, the increase of temperatures is observed from January to December and the values under the most pessimistic scenario (RCP8.5) are clearly higher than those obtained under the RCP4.5 scenario as shown in figure 6 . This situation will increase the evaporative demand from the atmosphere and could worsen the surface water shortage.

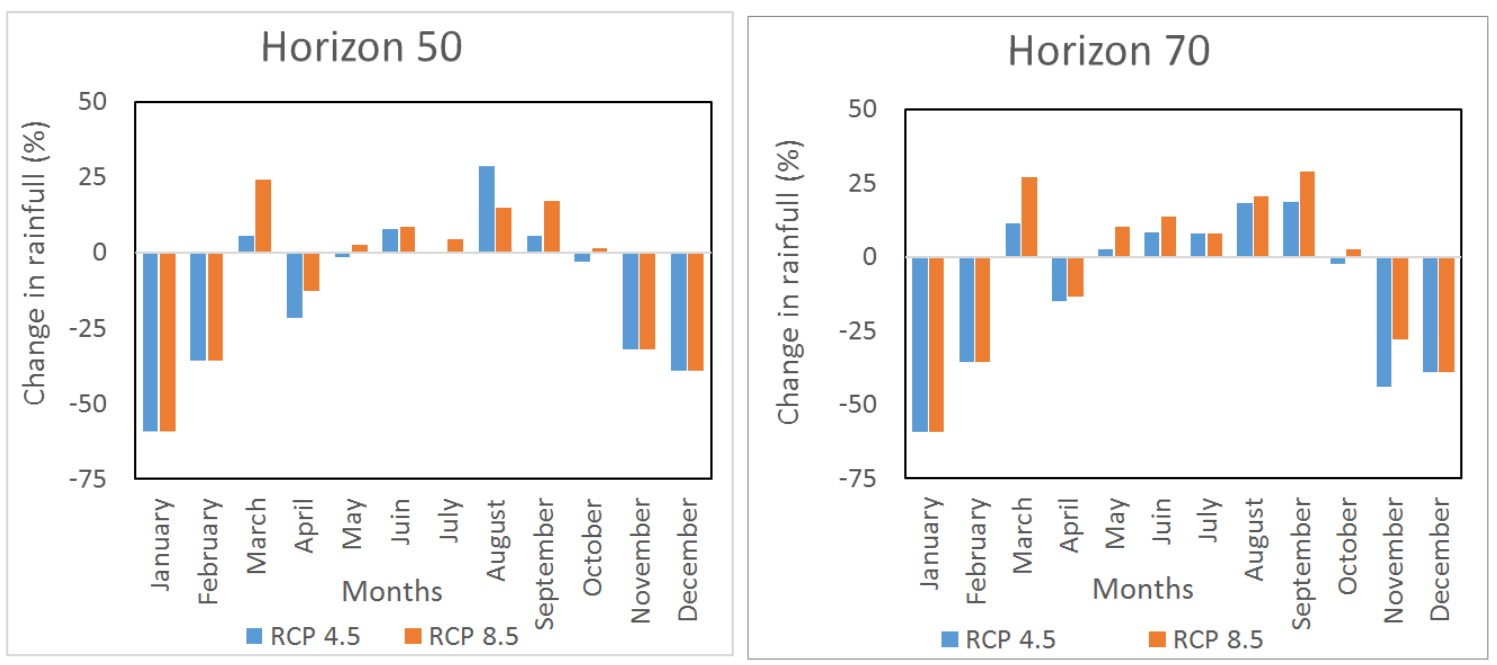

Figure 5. Change of projected monthly rainfall. 

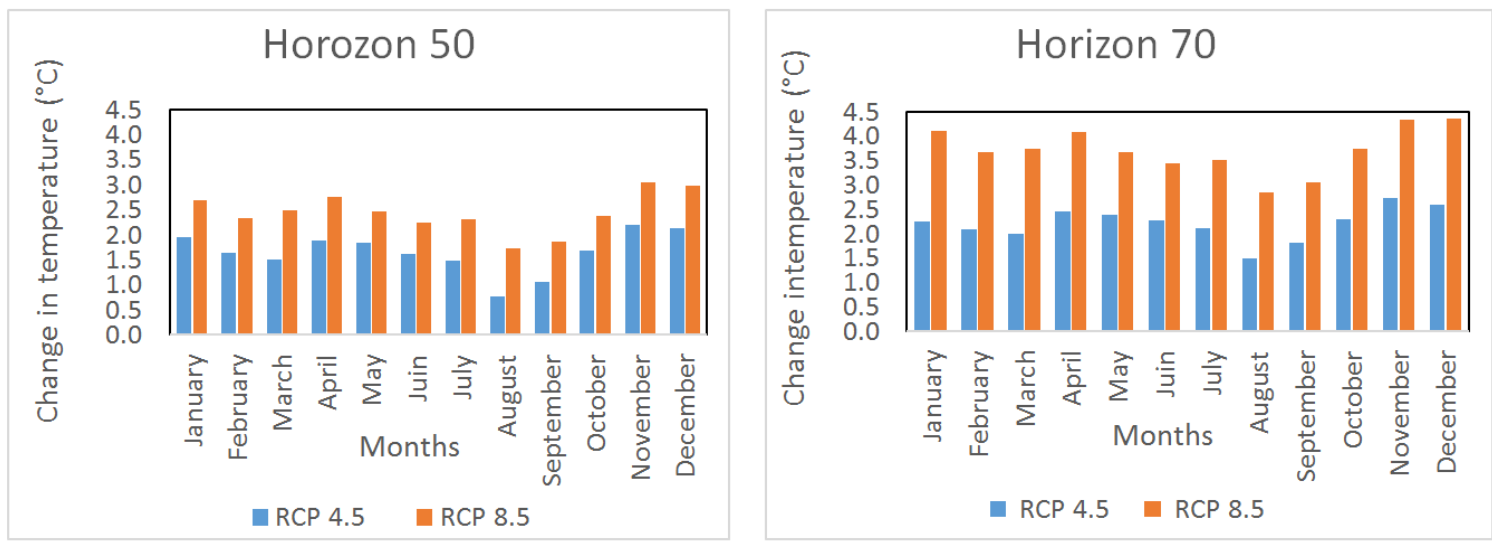

Figure 6. Change in projected monthly temperatures.

\subsection{Potential Impacts of Climate Change on Water Resources in the Sub-basin}

Figure 7 shows that the climate balance is negative from October to May and positive from June to September. The average monthly temperatures vary from $24.8^{\circ} \mathrm{C}$ in August, which coincides with the strongest climatic balance of about $+171.92 \mathrm{~mm}$, to $30.2^{\circ} \mathrm{C}$ in March, which has the most deficient climatic balance estimated at about $-134.36 \mathrm{~mm}$. In addition, the interannual climatic balance is globally negative and estimated on average at -292.92 $\mathrm{mm}$. These results show the reinforcement of the evaporating power, particularly from October to May, which corresponds to a climatic pressure on the water resources in general and surface water in the catchment area in particular.

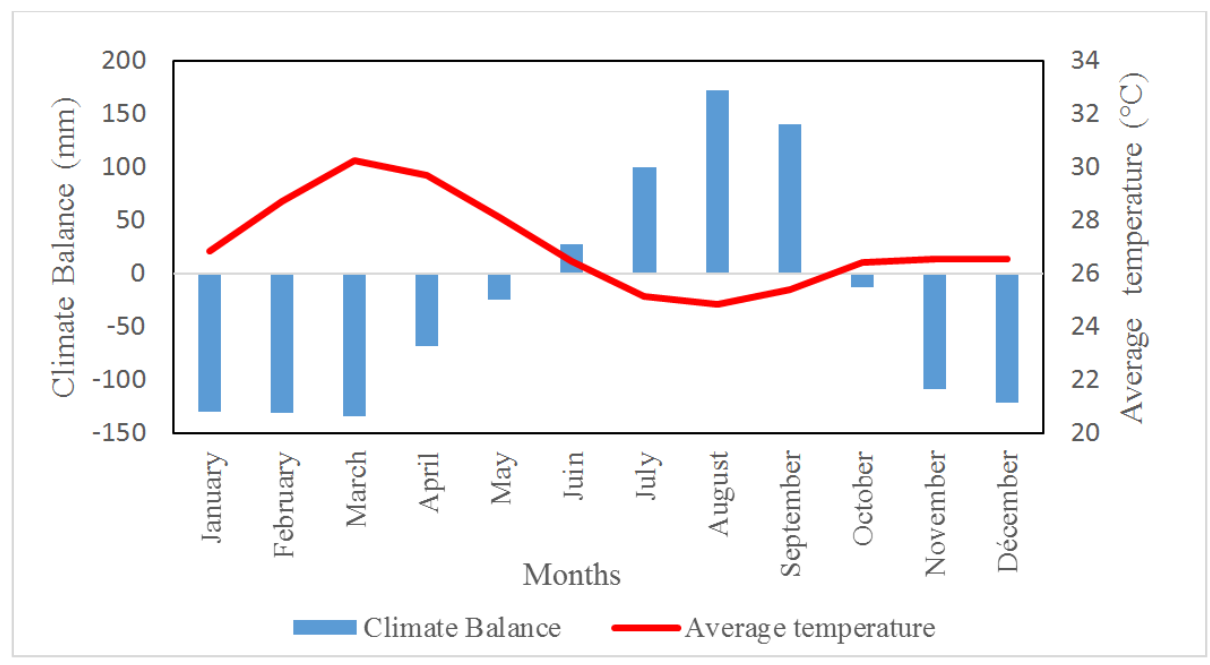

Figure 7. Average temperature and monthly climate balance.

\section{Discussion}

The decreasing rainfall trend is consistent with studies carried out in the Mekrou catchment by [13] and in border regions such as Burkina Faso [22, 23] and on the Kara basin in Togo $[18,24]$. The author [13] also noted a decrease in the flow of the Mekrou and the increase in dry years corroborating the results obtained by [15] in the Sudanian zone of Benin. Moreover, the temperature increase is in line with the results of [25] in West Africa and confirms once again the problem of global warming with its corollaries such as the increase in the evaporative capacity of the area and the pressure on surface water resources $[18,21,26]$. In the Oum Erbia water basin in Morocco, [27] also observed an increase in its average temperature. This situation, which could worsen in the future at the level of the Mekrou sub-basin at the outlet of Yakrigourou, will limit the availability of surface water resources and in turn impact the human population and agricultural activities as notified by [18] in 2019 in the Kara catchment.

\section{Conclusion}

The present study revealed that the Mékrou sub-basin at the Yakrigourou outlet, between the period 1965 - 2018 is characterized by a strong irregularity of rainfall with a downward trend estimated at about $14.4 \%$ and then an increase in dry years estimated at $54 \%$. Temperature, like in West Africa, has increased by $0.4^{\circ} \mathrm{C}$, while runoff has tended 
to decrease over the decade from 2007 to 2016. On an annual scale and according to the RCP 4.5 scenario, rainfall could increase by $6.62 \%$ at the horizon $2041-2060$ and by $8.29 \%$ at the horizon 2061-2080. On the most pessimistic scenario (RCP 8.5), those percentages rise respectively to $8.29 \%$ and $13.83 \%$. With regard to temperature, an increase is also expected whatever is the scenario and the period. The monthly climate balance is negative from October to May and positive from June to September. The results showed an increase of evaporative capacity, which corresponds to climatic pressure on surface water resources.

\section{References}

[1] Coalision Eau (2014). Water and climate change. Research note. France. p. 60 .

[2] Bates, B. C., Kundzewicz, Z. W. Wu, S. et Palutikof, J. P. (2008). Climate Change and Water, technical paper published by the intergovernmental Panel on Climate Change, IPCC Secretariat, Genève, 2008.

[3] GIEC, (2019). IPCC Special Report on the Consequences of Global Warming of $1.5^{\circ} \mathrm{c}$ Relative to Pre-industrial Level ond Associated Global Greenhouse Gas Emissions Trajectories, Against the Context of Strengthening the Global Response to Climate Change, sustainable development and the fight against poverty. ISBN 978-92-9169-253-8. P. 110.

[4] Ogouwalé E. (2006). Climate Change in southern and central Benin: indicators, scenarios and foresight of food security. «Thèse présentée pour obtenir le Diplôme de Doctorat Unique de l'Université d'Abomey-Calavi». P. 302.

[5] MEPN, (2010). Study of the vulnerability, impacts and adaptation of water resources to climat change in Benin, Cotonou, Bénin p. 97.

[6] Chédé F. (2012). Vulnerability and adaptation strategies to climate change of farmers in the collines department in Benin, «mémoire de Mastère changement climatique», Niamey, Agrhymet. p. 65.

[7] Boko M., Kosmowski F. et Vissin E. W. (2012). The issues of climate change in Benin, Konrad-Adenauer-Stiftung Program for Political Dialogue in West Africa, Cotonou, Bénin. p. 72.

[8] Yabi I. and Afouda F. (2012). Extreme rainfall years in Benin (West Africa), Quaternary International, 262 (7): 39-43, DOI: https://doi.org/10.1016/j.quaint.2010.12.010.

[9] Issa M. S. (2012). Climate Change and agro-systems in middles Benin: Impacts and adaptation strategies, «Thèse de doctorat unique de géographie», UAC/FLASH/EDP, p.278.

[10] Lawin A. E., Akponikpè P. B., Irénikatché, Jalloh A., Nelson C., Gerald and Thomas S. T. (2013). Chapter 3: Benin, pp, 53 - 77, In West African Agriculture and climate change: A comprehensive analysis, Edited by Abdulai Jalloh, Gerald C, Nelson, Timothy S, Thomas, Robert Zougmoré, and Harold Roy-Macauley. P. 408.

[11] Allé C. S. U. Y., Guibert H., Agbossou K, E., Gozé E. et Afouda A. (2013). Climate Change, perceptions and adaptations of producers on the Allada Plateau in southern Benin, European Journal of Scientific Research, 107 (4), pp, 530-545.
[12] MDAEP-Bénin, 2014, Modeling of the economic impact of climate change by development sector: water resources sector, Report commissioned by the Ministry of Development, Economic Analysis and Foresight, Cotonou, Bénin. p. 36.

[13] Vissin E. W. (2007). Impact of climate variability and the dynamics of surface conditions on the flows of the Benin watershed of the Niger River. "Thèse de doctorat, Université de Bourgogne». Dijon, France. p. 285.

[14] Obada E., Alamou A. E., Zandagba J., Chabi A. and Afouda A. (2017). Change in Future Rainfall Characteristics in the Mekrou Catchment (Benin), from an Ensemble of 3 RCMs (MPI-REMO, DMI-HIRHAM5 and SMHI-RCA4). Hydrology, 4, 14; doi: 10.3390/hydrology4010014.

[15] Yabi I. (2018). Rainfull drought in the Sudanese zone in Benin: Events and implications for climate-resilient agriculture. «Dynamiques Spatiales et Développement: Revue semestrielle du Laboratoire d'Etudes des Dynamiques Urbaines et Régionales.» numéro spécial 002: 115-134.

[16] Pilabina E. S. (2019). Climate dynamics in central and northern Togo «Thèse de doctorat. Université de Lomé». p. 320 .

[17] Koumassi D. H. (2014). Hydroclimatic risks and vulnerabilities of Ecosystems in the Sota watershed at the Coubéri outlet. «Thèse de doctorat unique de Géographie physique. Université d'Abomey-Calavi. Laboratoire Pierre PAGNEY. Climats. Eau. Ecosystèmes et Développement (LACEEDE)». p. 246.

[18] Pilabina S., Yabi I. et Kola E. (2019). Climate change and sensitivity of water resources in the Kara watershed in North Togo. «XXXII ème Colloque Internationale de l'AIC, Thessaloniki - Grèce».

[19] Aghrab A. (2003). Characterization of drought and development of climatic indicator for its early warming in the Sais region. «Ecole Nationale d'Agriculture de Meknès, Maroc». p. 109.

[20] Ardoin-Bardin S. (2004). Hydro-climatic variability and impacts on the water resources of large hydrographic basins in the Sudano-Sahelian zone. «Thèse de doctorat. Université de Montpellier II». p. 440.

[21] Totin V. H. S. 2010. Sensitivity of groundwater in the coastal sedimentary basin of Benin to climate change and exploitation methods: sustainable management strategies. "Thèse de doctorat unique de Géographie physique. Université d'Abomey-Calavi. Laboratoire Pierre PAGNEY. Climats. Eau. Ecosystèmes et Développement (LACEEDE)». p. 283.

[22] West C. T., Roncoli C. and Ouattara F. (2008). Local perceptions and regional climate trends on the Central Plateau of Burkina Faso. Land Degradation \& Development, pp. 289304.

[23] Sarr B., Atta S., Ly M., Salack S., Ourback T., Subsol S. and Alan George D. (2015). Adapting to climate variability and change in smallholder farming communities: A case study from Burkina Faso, Chad and Niger (CVCADAPT). Journal of Agricultural Extension and Rural Development. Vol. 7 (1), pp. 418-428, DOI: 10.5897/ JAERD 14.0595.

[24] Badjana H. M., Renard B., Helmschrot J., Edjamé K. S., Afouda A. and Wala K. (2017). Bayesian trend analysis in annual rainfall total, duration and maximum in the Kara River basin (West Africa). J Hydrol, 255-273. 
[25] CILSS Agrhymet (2015). Climate-smart agriculture: a winning solution to meet the challenge of food insecurity and the fight against desertification in the sahel and West Africa. Note to decision makers. Niamey. Niger. p. 9.

[26] Ogouwalé R. (2009). Hydro-pluviometric resources: state and trend in the upper Okpara watershed. "Mémoire du Diplôme d'Etudes approfondies (DEA) ». p. 75.
[27] Jouilil I., Bitar K., Salama H., Amaraoui, Momssit A. et Tahiri M. (2013). Meteorological drought in the Oum Er Rbia hydraulic basin during the last decades. Larhyss Journal, ISSN 1112-3680, n 12 , pp. 109-127. 